Selmani Bukleta M, Bukleta D, Selmani M, Kuhar M. Frequency of complete and removable partial denture treatment in the primary health centres in three different regions of Kosovo from 2002 to 2013. Zdr Varst. 2019;58(3):104-111. doi: 10.2478/sjph-2019-0014.

\title{
FREQUENCY OF COMPLETE AND REMOVABLE PARTIAL DENTURE TREATMENT IN THE PRIMARY HEALTH CENTRES IN THREE DIFFERENT REGIONS OF KOSOVO FROM 2002 TO 2013
}

\author{
POGOSTOST OSKRBE S TOTALNO IN DELNO PROTEZO V PRIMARNIH \\ ZDRAVSTVENIH CENTRIH V TREH RAZLIČNIH REGIJAH NA KOSOVU \\ V OBDOBJU 2002-2013
}

\author{
Manushaqe SELMANI BUKLETA ${ }^{1,2}$, Dashnor BUKLETA ${ }^{3}$, Mimoza SELMANI ${ }^{4}$, Milan KUHAR ${ }^{5^{*}}$ \\ 'University of Ljubljana, Medical Faculty, Doctoral School, Vrazov trg 2, 1000 Ljubljana, Slovenia \\ ${ }^{2}$ Dental Clinic, Mdent Family Dentistry, Eqrem Qabej 74, 10000 Pristina, Kosovo \\ ${ }^{3}$ Dental Polyclinic, Department of Oral Surgery, Nene Tereza NN, 30000 Peje, Kosovo \\ ${ }^{4} \mathrm{AAB}$ College, Zona Industriale, Fushe Kosove, 10000 Pristina, Kosovo \\ ${ }^{5}$ University of Ljubljana, Medical Faculty, Department for Prosthodontics, Hrvatski trg 6, 1000 Ljubljana, Slovenia
}

\section{ABSTRACT}

Keywords:

edentulism, prosthodontic treatment, complete dentures, removable partial dentures

Introduction: Edentulism and prosthodontic care are very common, especially in the elderly. The study investigated the treatment with complete dentures (CDs) and acrylic removable partial dentures (ARPDs) among people receiving new prosthodontic treatment in the Primary Health Centres of the three regions in Kosovo from 2002 to 2013.

Methods: The data on ARPDs delivery and CDs delivery was obtained from the archives of primary health centres from three Kosovo regions (Prizren, Peje, Ferizaj) from 2002 to 2013. The data was analysed concerning year of treatment, type of dentures, jaw, age, gender and urban or rural origin of the patients. The trend of treatment was determined, and the binomial logistic regression model was used for predicting odds of ARPD versus $C D$ treatment by year of treatment and patient characteristics.

Results: From 2002 to 2013, 9,478 patients received 11,655 CDs and 4,401 ARPDs. Delivery of CDs significantly increased by 57.45 dentures per year $(R 2=0.609)$ and delivery of $A R P D s$ by 30.39 dentures per year $(R 2=0.569)$. Each year the odds for ARPD versus CD increased by $4.2 \%$ (95\% Cl: $3.0 \%-5.4 \%)$. Younger patients have higher odds for ARPD rather than CD and odds for ARPD are decreasing as the age of patients rises. The gender, residence, and jaw all had a significant impact on prosthodontic treatment too.

Conclusions: In Primary Health Centres of Kosovo, there is a trend for higher frequencies of both dentures (more obvious for ARPD), and the frequency is highly dependent on the age of patients.

Uvod: Brezzobost in protetična oskrba sta zelo pogosti, še zlasti pri starejših osebah. $V$ študiji so preučevali zdravljenje s totalnimi in akrilatnimi delnimi protezami pri osebah, ki so v obdobju od 2002 do 2013 prejele novo protetično oskrbo $v$ primarnih zdravstvenih centrih $v$ treh regijah na Kosovu.

Ključne besede: brezzobost, protetična oskrba, totalne proteze, delne proteze

Metode: Iz arhivov primarnih zdravstvenih centrov na Kosovu (Prizren, Peje in Ferizaj) so bili iz obdobja od 2002 do 2013 zbrani podatki o vstavljenih novih totalnih in akrilatnih delnih protezah. Analizirani so bili glede na leto vstavitve, vrste protez, prisotnosti protez v zgornji in/ali spodnji čeljusti, starost, spol in prebivališče (mesto, podeželje) oskrbovancev. Od leta 2002 do 2013 so določili trend pogostosti oskrbe s protezama. Za napovedovanje verjetnosti oskrbe $\mathrm{z}$ delno protezo $\mathrm{v}$ primerjavi s totalno protezo glede na leto, ko je bila proteza vstavljena, in značilnosti bolnikov so uporabili binomsko logistično regresijo.

Rezultati: V študiji je bilo zajetih 9.478 bolnikov, ki so jim vstavili 11.655 totalnih protez in 4.401 akrilatnih delnih protez. Število vstavitev totalnih protez se je v letih 2002-2013 pomembno povečevalo za 57,45 na leto $(R 2=0,609)$, vstavitev akrilatnih delnih protez pa za 30,39 na leto $(R 2=0,569)$. Vsako leto se je obet za vstavitev akrilatne delne proteze glede na totalno protezo povečal za 4,2 \% (95\%, Cl: 3, 05, 4 \%). Mlajši pacienti imajo večje obete za oskrbo z akrilatno delno protezo kot za oskrbo s totalno protezo. Verjetnost zdravljenja z akrilatno delno protezo se s staranjem zmanjšuje. Statistično značilen vpliv na protetično zdravljenje so imeli tudi spol in prebivališče pacientov ter lokacija proteze $v$ ustih.

Sklepi: V primarnih zdravstvenih centrih na Kosovu se povečuje pogostost oskrbe z obema zobnima protezama (intenzivneje pri akrilatni delni protezi) in pogostost je močno odvisna od starosti pacientov. 


\section{INTRODUCTION}

Thanks to preventive dentistry, which was introduced in the mid-20 $0^{\text {th }}$ century, most people are now aware that natural teeth can be maintained throughout an entire lifetime (1-3). In developed countries, the prevalence and extent of tooth loss has significantly decreased in recent decades $(1,2,4,5)$. The prevalence of edentulism decreased by approximately $4-10 \%$ over ten years $(1,5$, 6). However, the growing population of elderly, which will continue to grow dramatically in the next few decades, is the main reason for the persistence of high levels of edentulism $(1,7)$. Consequently, prosthodontic care is prevalent, especially in the elderly, in most European countries $(8,9)$. Correlations between the prevalence of edentulism and prosthodontic care as well as national prosperity, irregular-regular visits to the dentist, urbanrural residence, age, gender, and education were also demonstrated $(1,10)$.

The primary purpose of prosthodontic care is to replace missing teeth and to restore function and aesthetics, as well as to preserve the health of the remaining oral tissues of partially or completely edentulous patients. The prosthodontic treatment combines several clinical and laboratory procedures that lead to the insertion of the fixed (crowns and bridges) or removable (partial and complete dentures) prosthodontic device (11). In principle, because treatment with various types of removable dentures is generally less successful than with fixed prosthodontic devices, removable prosthodontic treatment is indicated when clinical or financial factors exclude fixed prosthodontic treatment on teeth or dental implants (12-14). In the last three decades, the removable dentures supported by dental implants have proven to be a very successful form of prosthodontic treatment for edentulous people and treatment with them is continuously increasing. However, due to increased complexity (needs surgery) and higher costs are significantly less common than conventional denture treatment without dental implants $(15,16)$.

Currently, conventional mucosa-born complete dentures (CDs) are still the most common removable form of prosthodontic treatment for complete edentulous jaws, while conventional mucosa and teeth-born removable partial dentures (RPDs) of all types continue to be a standard treatment modality in the maxillary and mandibular partial edentulous arches (17). The RPDs with a metal framework (MRPDs) and acrylic based RPDs without a metal framework (ARPDs) are the most commonly used removable partial dentures (8). More expensive and technically more demanding MRPDs have some crucial advantages over ARPDs. The main advantages are better dental support, oral tissue release from the extended resin plate coverage, and facilitated maintenance of hygiene, which impacts the higher success rate of MRPDs.
Mobility of abutment teeth and fracture of dentures are observed more often in ARPDs than in MRPDs $(18,19)$. A study among general dentists in Ireland showed that the average survival rate of an ARPD is 5.7 years, whereas an MRPD has an average survival rate of 10.6 years (20).

Data on prosthodontic care in different countries, environments, and patient groups can be relevant, in particular to all those who are involved in planning and organizing healthcare, as well as in health education $(15,21)$. Epidemiological studies published from 2004 to 2013 show that, of all RPDs constructed, the acrylic without metal framework ones were used in $3.2-75 \%$ of cases in different countries $(17,20,22-24)$. A review study of 43 articles, which related to 13 European countries, concluded that there is a trend toward a higher prevalence of fixed prosthodontic treatments, more various types of RPDs and a reduction in CDs in most European countries. The majority of these articles presented the prevalence of various prosthodontic devices at a given time, and only five articles presented the incidence of newly used prosthodontic treatments over a specific period (8). A study performed in Croatia shows that Croatian Health Insurance has been covering the cost of CDs, ARPDs, and MRPDs for the past twenty years. At the same time, an upward trend particular to MRPDs has been detected in the majority of Croatian regions (25). Since 2013, the costs of MRPD treatment have been covered by health insurance in Slovenia as well (26). Subjective clinical estimations show an upward trend in the use of MRPDs since that date but, unfortunately, this has not yet been scientifically confirmed. Ever since the war in 1999, primary health centres in Kosovo only provide low-cost prosthodontic treatment, which means that edentulous persons are treated with either ARPDs or CDs. A considerable number of patients seek medical and dental services in these centres, and most of them are socially deprived, war veterans, relatives of war victims and older adults. Treatment with MRPD as a more advanced form of the removable partial dentures is only available in the statefunded University Clinical Centre in Pristina, Kosovo. In other institutions, the patients need to pay MRPD, like fixed restorations, by themselves.

No epidemiological studies have been made on the use of any prosthodontic treatment in the Republic of Kosovo. The purpose of the study was to investigate the treatment with CDs and ARPDs among people receiving prosthodontic treatment in the Primary Health Centres of the three regions in Kosovo. Therefore, the aims of this study were: 1) to find out what was the trend in the frequency of new treatments with CDs and ARPDs from 2002 to 2013; 2) to analyse the relationship between two prosthodontic treatments (ARPDs versus CDs) and according to different factors (age, sex, jaw, living environment); 3) to determine the proportion of the population receiving new $C D$ and ARPD treatment at the annual level by age. 


\section{METHODS}

This study included all patients who received new prosthodontic treatment with CDs and ARPDs at Primary Health Centres of three Kosovo regions: Prizren, Peje (Peč) and Ferizaj (Uroševac) from 2002 to 2013 (Table 1). $35.2 \%$ of the total data comes from Prizren, 37.2\% from Peja, and $27.6 \%$ from Ferizaj. The data collected from the archives of primary health centres included: the year of delivery of the denture, the type of the denture delivered (CD or ARPD), the location of the denture in the patient's mouth (maxilla, mandible), the patient gender, the urban or rural origin of the patient, and the age of the patient upon denture delivery.

This study includes 9,478 patients who received treatment with CDs and ARPDs. $72.1 \%$ of patients live in urban areas and only $27.9 \%$ in rural areas. The participants were divided into 6 age groups as follows: younger than 35 years of age (1.9\%), 35 to 44 years of age $(8.9 \%), 45$ to 54 years of age (21.8\%), 55 to 64 years of age (26.0\%), 65 to 74 years of age $(30.8 \%)$ and more than 75 years of age (10.5\%).

Table 1. The number of patients according to the number and type of dentures they received in prosthodontic treatment in the Primary Health Centres of the three regions of Kosovo from 2002 to 2013.

\begin{tabular}{lccc}
\hline Patients & \multicolumn{3}{c}{ Dentures } \\
\cline { 2 - 4 } & CD & ARPD & Total \\
\hline $\mathbf{4 , 4 8 3}$ & 8,966 & & 8,966 \\
$\mathbf{1 , 6 4 7}$ & 1,647 & & 1,647 \\
$\mathbf{1 , 0 4 2}$ & 1,042 & 1,042 & 2,084 \\
$\mathbf{1 , 0 5 3}$ & & 2,086 & 2,106 \\
$\mathbf{1 , 2 5 3}$ & & 1,253 & 1,253 \\
$\boldsymbol{\Sigma 9 , 4 7 8}$ & $\boldsymbol{\Sigma} 11,655$ & $\boldsymbol{\Sigma 4 , 4 0 1}$ & $\boldsymbol{\Sigma} 16,056$ \\
\hline
\end{tabular}

The obtained data was statistically analysed using SPSS 22.0 statistical package. The separate linear trends for $C D$ and ARPD treatment were calculated. To draw inference from our data and to lose the outliers, we have normalized the data into a range of between zero and one. The absolute number, as well as the normalized values of the delivered CDs and ARPDs for each year of delivery, are presented in the graphs.

A prediction of ARPD treatment versus CD treatment in people receiving prosthodontic care from 2002 to 2013 was statistically analysed using binomial logistic regression. Sex, age, residence and denture location in the jaw were proposed as categorical covariates and the year of denture delivery as a continuous covariate. The adjusted odds ratios (AORs) and $95 \%$ confidence interval $(95 \% \mathrm{Cl})$ are presented. For statistical significance, $\mathrm{p}$-values $<0.05$ were considered.

To calculate the proportion of the population that is on an annual basis receiving new dentures in Public Health Centres, a four-year (2010-2013) average of patients who received CDs or ARPDs and population data from the last census were used. At the same time, patients and the population in all three investigated regions were arranged into six age groups (<35, 35-44, 45-54, 55-64, 65-74, 75+), in the age group $35+$ and to all ages (total). The population for each age group was based on the data from the 2011 population census in the Republic of Kosovo (27). Of the $1,739,825$ residents of Kosovo registered in the year 2011, the number living in Prizren, Peje, and Ferizaj was 382,841 (22\% of the total number of residents in Kosovo) (Table 2).

Table 2. Population size in the three regions of Kosovo registered in 2011.

\begin{tabular}{lcccc}
\hline Age group & Prizren & Peje/Peč & $\begin{array}{c}\text { Ferizaj/ } \\
\text { Uroševac }\end{array}$ & Total \\
\hline$<35$ & 111,468 & 57,811 & 69,212 & 238,491 \\
$\mathbf{3 5 - 4 4}$ & 24,767 & 13,150 & 14,750 & 52,667 \\
$\mathbf{4 5 - 5 4}$ & 18,452 & 10,658 & 10,822 & 39,932 \\
$\mathbf{5 5 - 6 4}$ & 11,690 & 7,337 & 7,269 & 26,296 \\
$\mathbf{6 5 - 7 4}$ & 7,443 & 4,917 & 4,570 & 16,930 \\
$\mathbf{7 5 +}$ & 3,961 & 2,577 & 1,987 & 8,525 \\
Total & 177,781 & 96,450 & 108,610 & 382,841 \\
\hline
\end{tabular}

\section{RESULTS}

In the Primary Health Centres of all three regions of Kosovo, 9,478 patients received 16,056 removable dentures, of which 6,130 (64.7\%) patients received only CDs, 2,306 (24.3\%) patients received only ARPDs, and $1,042(11.0 \%)$ patients received both CD and ARPD from 2002 to 2013.

The absolute number of the new treatments with CDs and ARPDs for each year of denture delivery, as well as the trends of the normalized frequencies of the treatment with CDs and ARPDs from the year 2002 to 2013, are presented (Figures 1 and 2). There is a significant upward trend line in the treatment with CDs: $p=0.003, R 2=0.609$. On average, the absolute number of $C D$ deliveries increase by $57.45 \mathrm{CDs}$ per year. Results regarding ARPDs show that there is a significant rising trend in their delivery as well: $p=0.005, R 2=0.569$. On average, the absolute number of ARPD deliveries increase by 30.39 per year. Although the average increase of the absolute number of $C D$ deliveries is higher than the average increase of the 
absolute number of the ARPD deliveries, the normalized data shows that the average number of ARPD deliveries increases more rapidly than the average number of $C D$ deliveries. To further verify these findings, the odds for receiving $A R P D s$ versus $C D$ s - dependent on the years of delivery - were calculated.

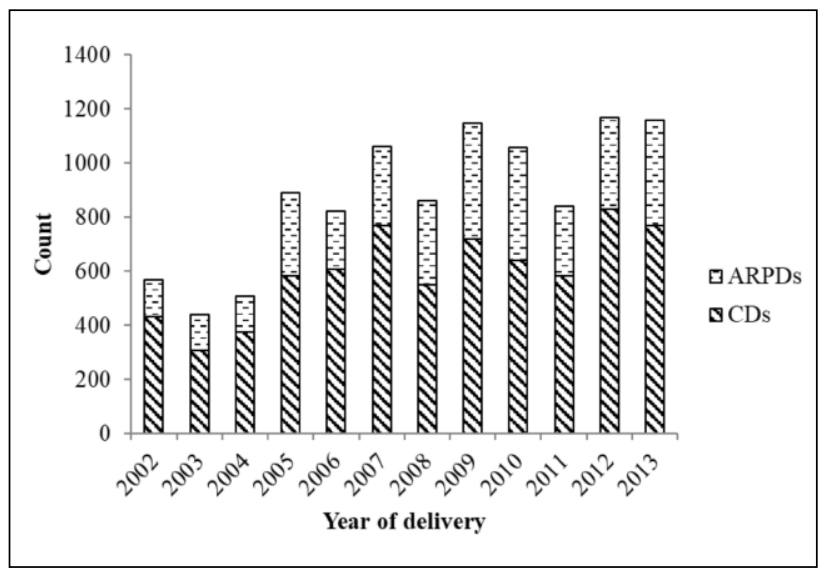

Figure 1. The number of new treatments with CDs and ARPDs for each year of denture delivery in the Primary Health Centres of Kosovo.

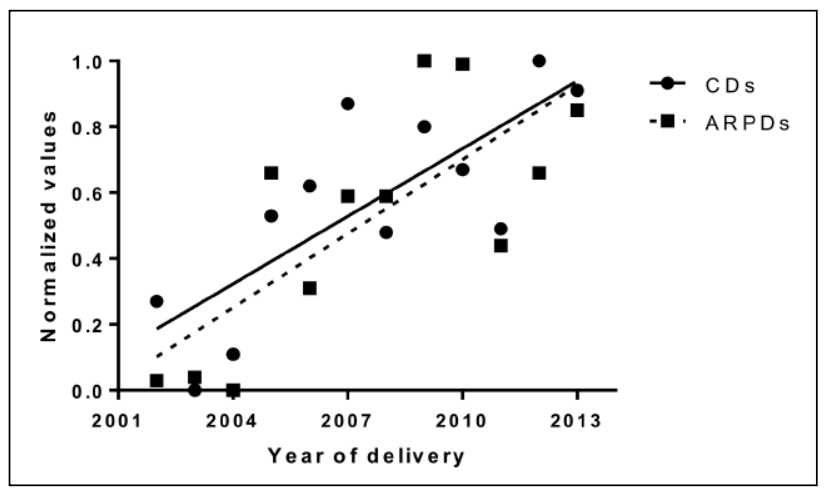

Figure 2. The linear trend of $C D$ and ARPD delivery in three regions of Kosovo from 2002 to 2013.

To determine the effects of age, gender, residence and denture location on the likelihood of the type of the denture treatment among the patients, a binomial logistic regression model was conducted (Table 3 ). The model explained 14.7\% (Nagelkerke R2) of the variance in the type of denture predicted and correctly classified $73.9 \%$ cases.
The results indicate that the year of delivery was statistically significant: $p<0.05$. Each year the odds for treatment with ARPD versus CD increased by $4.2 \%$ (95\% Cl: $3.0 \%-5.4 \%$ ). Males have $29.1 \%$ higher odds for treatment with ARPD rather than CD. In comparison with the reference group (older than 75) patients younger than 34 years have the highest odds for treatment with ARPD ( $A O R=13.935 ; 95 \% \mathrm{Cl}: 10.296-18.861)$ rather than $C D$ and odds for ARPD are decreasing as the age of patients rises. Moreover, in comparison with the same reference group (older than 75) all compared age groups have higher odds for treatment regarding ARPD versus CD. Significant results were also found regarding the residence of the patients. Compared with patients from urban residence, patients from rural residence have $10.2 \%$ higher odds for treatment with ARPDs over CDs. Results indicate that it is more likely for patients to receive ARPD than CD treatment on the mandibula than maxilla ( $A O R=2.996$; 95\% Cl: 2.778-3.231).

Table 3. Binominal logistic regression model predicting odds of ARPD versus CD treatment by year of receiving the treatment (2002-2013) and patient characteristics.

\begin{tabular}{|c|c|c|c|}
\hline $\begin{array}{l}\text { Observed } \\
\text { category }\end{array}$ & $\begin{array}{l}\text { Reference } \\
\text { category }\end{array}$ & $\begin{array}{l}\text { AOR }(95 \% \mathrm{Cl}) \\
\text { ARPD to CD }\end{array}$ & $\mathrm{p}$ \\
\hline \multicolumn{4}{|c|}{ Year of delivery } \\
\hline 2013 & 2002 & $1.042(1.030-1.054)$ & $0.001^{*}$ \\
\hline \multicolumn{4}{|l|}{ Sex } \\
\hline [Male] & [Female] & 1.291 (1.197-1.392) & $0.001^{*}$ \\
\hline \multicolumn{4}{|l|}{ Age } \\
\hline$[<34$ years $]$ & {$[75+$ years $]$} & $13.935(10.296-18.861)$ & $0.001^{*}$ \\
\hline [35-44 years] & [75+ years] & $6.201(5.181-7.422)$ & $0.001^{*}$ \\
\hline [45-54 years] & [75+ years] & $3.541(3.031-4.137)$ & $0.001^{*}$ \\
\hline [55-64 years] & [75+ years] & $2.519(2.163-2.934)$ & $0.001^{*}$ \\
\hline [65-74 years] & [75+ years] & $1.512(1.299-1.759)$ & $0.001^{*}$ \\
\hline \multicolumn{4}{|l|}{ Residence } \\
\hline [Rural] & [Urban] & $1.102(1.008-1.205)$ & $0.033^{*}$ \\
\hline \multicolumn{4}{|l|}{ Jaws } \\
\hline [Mandibula] & [Maksila] & $2.996(2.778-3.231)$ & $0.001^{*}$ \\
\hline
\end{tabular}

*marks statistically significant differences $(p<0.05)$

From 2010 to 2013, at an annual level, $0.18 \%$ of the total population in three Kosovo regions received a new CD and $0.09 \%$ a new ARPD in the Public Health Centres. In the $35+$ year-old population, the proportion of the population treated with new CDs was $0.48 \%$ and $0.23 \%$ for new ARPDs. The proportion gradually increased with the increasing age of recipients of dentures up to the 75+ age group, and a decrease was detected in the $75+$ age group (Figure 3 ). 


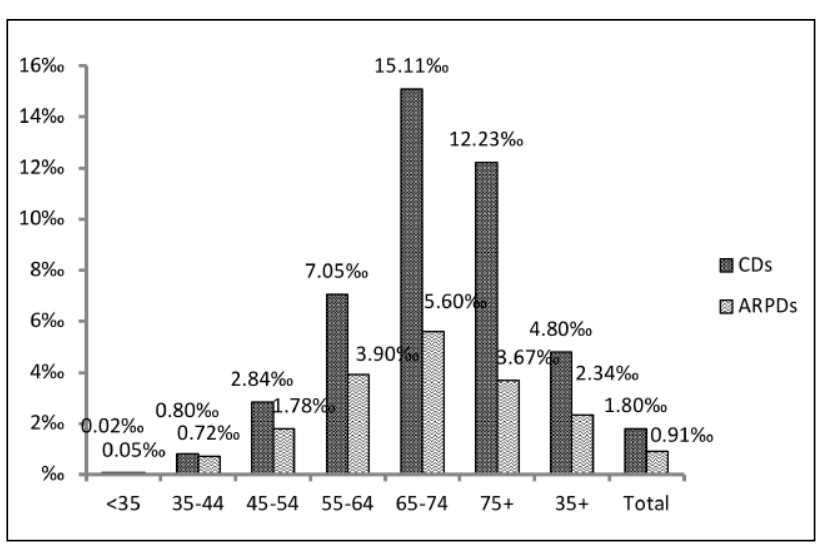

Figure 3. The distribution of the proportion of population treated with CDs and ARPDs from 2010 to 2013, at an annual level, by the age groups $>35,35-44,45-54$, $55-64,75+, 35+$ and in total.

\section{DISCUSSION}

In the primary health centres in the three Kosovo regions combined, where almost a quarter of Kosovo's inhabitants live, treatment with CDs was more than twice as frequent as treatment with ARPDs over the entire period of 20022013. Among those who were seeking prosthodontic care in these centres, most of them are completely edentulous, and the most commonly used prosthodontic devices are CDs. In the same centres, the absolute number of removable prosthodontic treatments with both dentures rose continuously from 2002 to 2013 . The increase in treatment with CDs was significantly higher (more than 27 treatments per year on average) than in the case of treatment with ARPDs. In most European countries, however, there has been a clear trend toward reducing removable prosthodontic devices, especially CDs (7-9). In contrast to our study, the frequency of treatment with CDs in Croatia was significantly lower than the frequency of treatment with RPDs from 1996 to 2002 (23). Similarly, the trend toward increasing the frequency of fixed prosthodontics devices and RPDs and the reduction of CDs has been identified in thirteen other European countries $(8,9)$. Unfortunately, these studies differ significantly concerning age, socioeconomic status, and origin of subjects as well as providers of dental care. Therefore, we can only compare trends, while a direct comparison of data is difficult. The data of our study is obtained from Primary Health Centres, where only primary dentists perform prosthodontic care. While the study in Croatia also includes institutions where specialists perform prosthodontic care. It should also be noted that in these centres dental care is provided to the most vulnerable groups of people in Kosovo. Given that edentulism is the main factor dictating the need for treatment with the $C D$
$(7,8)$, we can conclude that there is a high probability that the number of edentulous patients in the Primary Health Centres in Kosovo has also increased from 2002 to 2013.

The normalized frequencies of the treatment with CDs and ARPDs and, in particular, logistic regression predictions of ARPD treatment probability compared to CD by the year of treatment (2002-2013) reveals more interesting data on trends that were previously covered with high absolute values of CD treatment. The probability of ARPD deliveries versus $C D$ significantly increases over the years, and $C D$ deliveries decrease. A more detailed analysis revealed that, in the background of unfavourable absolute values of prosthodontic treatment trends, there is a slight drop in CD delivery in comparison with ARPD delivery, which is also reflected by a slight drop in edentulism. It is also more likely that ARPDs are more commonly used for the prosthodontic treatment of younger patients and, vice versa, that CDs are more often used than ARPDs for the prosthodontic treatment of the elderly. The prevalence of edentulism is most affected by the aging of the population $(1,7,10)$. According to the Kosovo Agency of Statistics, the number of people aged 35 years and older increased by $25.0 \%$ between 1991 and 2011 (27). Our results also show that the aging of the population is one of the important factors that affects prosthodontic treatment, as the probability of $C D$ treatment increased with the age of the patient. The proportion of ARPDs compared to CDs decreased with the age of patients and at the same time increased over the years. As the number of lost teeth increases with age, it is quite reasonable that, with the increasing age of patients, the CD and ARPD treatment ratio gradually tilts to the side of the $C D$, which is evident in our and many other studies $(8,28)$. However, aging is not the only factor affecting the frequency of edentulism and its treatment, since treatment with CDs increased by more than $100 \%$ in this same period.

In addition to the year of treatment and age of patients, many additional factors are described that have an impact on the frequency of prosthodontic care and edentulism $(8,9)$. The additional factors that were available to us in Primary Health Centres - gender, urban versus rural residence and mandibula versus maxilla as denture sites - have had a significant impact on prosthodontic treatment. Treatment with ARPD is more likely to occur in male subjects and people in a rural environment, and CD treatment is more likely in women and people from an urban environment. An appropriate explanation for the more likely deliveries of CDs in an urban environment is currently difficult to justify. Further investigation will be necessary to clarify this. 
The results of this study lead us to conclude that CD treatments were significantly more likely in the maxilla than in the mandible and ARPD treatments were more likely in the mandibula. Similarly, studies in Western European countries have found a higher frequency of treatment with a removable partial denture in the mandible $(29,30)$.

The present study shows that the proportion of the population treated with CDs and ARPDs per year steadily increased from the $<35$ up to the $75+$ age group and decreased in the $75+$ age group. Similarly, findings from a study in Croatia indicate that the delivery of prosthodontic appliances in the oldest age group dropped significantly. A less frequent delivery of $C D$ s to persons who are 75 years of age or older can be explained by the fact that older adults rarely visit a dentist, wear prostheses for a more extended period than younger persons, and replace old dentures with new ones less frequently $(15,21,25,28)$.

An important fact is that every prosthodontic treatment also has unwanted side effects and, especially if it is inadequate, harms oral health and tooth loss (29-32). In the contemporary planning of prosthodontic treatment, RPD is indicated when indications for fixed prosthodontic treatment on teeth or implants are ruled out due to biological or socioeconomic factors. It is therefore not surprising that RPD treatment generally has a lower survival rate, more complications and is less comfortable for the patient than fixed prosthodontic treatment (12-14, 32). According to our study, the Primary Health Centres in Kosovo have witnessed a continually growing trend of ARPD delivery in the period from 2002 to 2013. Furthermore, both the absolute number of ARPDs delivered and their proportion in comparison to CDs has increased. In Croatia, Slovenia and many developed countries, the proportion of RPDs in comparison to CDs has also been increasing, but mainly due to an increase in the proportion of MRPDs and a decrease in the proportion of ARPDs $(8,22,25,28)$. MRPDs have significantly better survival and success rate and, above all, improve the survival of the supporting teeth compared to ARPDs $(14,18-20)$. In the Primary Health Centres of Kosovo, only ARPDs are used for the treatment of partial edentulism. Consequently, although many individuals in these centres met the clinical criteria for a fixed prosthesis or even an MRPD, they were treated with ARPDs, even though these were less appropriate. Except at the University Clinical Centre in Priština, the patients themselves cover the cost of MRPD treatment, which is beyond the reach of most patients looking for dental care in the Primary Health Centres in Kosovo. Treatment with ARPDs can lead to rapid loss of remaining teeth and can increase the overall level of complete edentulism, thereby increasing the need for treatment with a CD $(31,32)$.
This study undoubtedly has certain limitations, mainly because the prevalence of edentulism was deduced from new dentures treatments. We must be aware that the real prevalence of edentulism in Kosovo is significantly higher than the proportion of new denture treatment. Namely, the data from Primary Health Centres included no information on how long individual patients wore dentures for. According to the population census in Kosovo (25), $61.7 \%$ of the population was living in rural areas in 2011. On the other hand, almost three-quarters of patients who received dentures in Primary Health Centres came from the urban environment, which leads us to conclude that only a small proportion of the rural population received dentures in these centres. This may either mean that people in rural areas had better oral health and had less edentulism or, more likely, that they visited a dentist less frequently, were edentulous and without dentures or were using dentures for a long time and rarely changed them. When interpreting the results of this study, it should be borne in mind that our investigated population represents the most vulnerable groups of people in Kosovo.

The number of preserved natural teeth and, indirectly, the presence of prosthodontic restorations is a significant indicator as well as a factor of oral and general health $(8$, 33). Data on the trend in the frequency of prosthodontic treatment can be important for developing national dental health services and dental health policy, as well as for dental school and research programs in Kosovo and the wider region. Sufficient dental centres that offer adequate care should be made available. In the case of prosthodontic care, this means that partial edentulism should be treated based on the professional indication, including with fixed prostheses and MRPDs, not only ARPDs. Considering the model of the neighbouring countries, the possibility of financing dental treatment, at least with MRPDs, could also be considered in Kosovo.

\section{CONCLUSIONS}

The trend in the frequency of new CD and ARPD treatment increased linearly from 2002 to 2013 in the Primary Health Centres in three regions of Kosovo. The need for CD treatment in absolute numbers is more than twice as high as the need for treatment with ARPD.

However, the proportion of ARPDs compared to CDs significantly increased over the years. Younger people have higher odds for treatment with ARPD and odds for ARPD are decreasing as the age of patients rises. Males have higher odds for treatment with ARPD. Patients from the rural environment have higher odds for treatment with ARPDs. CD treatments are more likely in the maxilla, and ARPD treatments are more likely in the mandibula. 
In the period of 2010-2013, the proportion of the population treated with new CDs and ARPDs per year steadily increased from the $<34$ to $65-74$ age group and decreased in the $75+$ age group. $0.48 \%$ of the population older than 34 years of age received new CDs, and $0.23 \%$ received new ARPDs in these centres.

Professional guidelines for treatment should be taken into consideration as much as possible, to improve oral health in people who need prosthodontic care, while efforts should also be made to reduce the impact of disadvantaged socio-economic factors on treatment decision, especially in older individuals and others seeking dental care in Primary Health Centres in Kosovo.

\section{CONFLICTS OF INTEREST}

The authors declare that no conflicts of interest exist.

\section{FUNDING}

There is no financial interest or risk.

\section{ETHICAL APPROVAL}

Received from the Professional Ethics Committee of the Hospital and University Service of Kosovo, University Clinical Centre of Kosovo, Pristina, prot. no. 555.

\section{REFERENCES}

1. Li KY, Wong MC, Lam KF, Schwarz E. Age, period, and cohort analysis of regular dental care behavior and edentulism: a marginal approach. BMC Oral Health. 2011;11:9. doi: 10.1186/1472-6831-11-9.

2. Douglass $\mathrm{CW}$, Jette $\mathrm{AM}$, Fox $\mathrm{CH}$, Tennstedt $\mathrm{SL}$, Joshi A, Feldman HA. Oral health status of the elderly in New England. J Gerontol. 1993;48:39-46.

3. Šket $T$, Kukec A, Kosem R, Artnik B. The history of public health use of fluorides in caries prevention. Zdr Varst. 2017;56:140-6. doi: 10.1515/sjph-2017-0018.

4. Osterberg T, Carlsson GE, Sundh W, Fyhrlund A. Prognosis of and factors associated with dental status in the adult Swedish population, 1975-1989. Community Dent Oral Epidemiol. 1995;23:232-6.

5. Sanders AE, Slade GD, Carter KD, Stewart JF. Trends in the prevalence of complete tooth loss among Australians, 1979-2002. Aust N Z J Public Health. 2004;28:549-54.

6. Wu B, Liang J, Landerman L, Plassman B. Trends of edentulism among middle-aged and older Asian Americans. Am J Public Health. 2013;103:76-82. doi: 10.2105/AJPH.2012.301190.

7. Turkyilmaz I, Company AM, McGlumphy EA. Should edentulous patients be constrained to removable complete dentures?: the use of dental implants to improve the quality of life for edentulous patients. Gerodontology. 2010;27:3-10. doi: 10.1111/j.1741-2358.2009.00294.

8. Zitzmann NU, Hagmann E, Weiger R. What is the prevalence of various types of prosthetic dental restorations in Europe? Clin Oral Implants Res. 2007;18(Suppl 3):20-33. doi: 10.1111/j.1600-0501. 2007.01435
9. Wanyonyi $\mathrm{KL}$, Radford $\mathrm{DR}$, Gallagher JE. Dental treatment in a state-funded primary dental care facility: contextual and individual predictors of treatment need? PLoS One. 2017;12:e0169004. doi: 10.1371/journal.pone.0169004. eCollection 2017.

10. Hugo FN, Hilgert JB, de Sousa Mda L, da Silva DD, Pucca GA Jr. Correlates of partial tooth loss and edentulism in the Brazilian elderly. Community Dent Oral Epidemiol. 2007;35:224-32. doi: 10.1111/j.0301-5661.2007.00346.

11. The glossary of prosthodontic terms. 9th Ed. J Prosthet Dent. 2017;117:e1-e105. doi: 10.1016/j.prosdent.2016.12.001.

12. Vermeulen A, Keltjens $H$, van Hof MA, Kayser AF. Ten-year evaluation of removable partial dentures: survival rates based on retreatment, not wearing and replacement. J Prosthet Dent. 1996;76:267-72. doi. org/10.1016/S0022-3913(96)90170-5.

13. Pjetursson BE, Bragger U, Lang NP, Zwahlen M. Comparison of survival and complication rates of tooth-supported fixed dental prostheses (FPDs) and implant-supported FPDs and single crowns (SCs). Clin Oral Impl Res. 2007;18(Suppl 3):97-113. doi: 10.1111/ j.1600-0501.2007.01439.

14. Etman MK, Bikey D. Clinical performance of removable partial dentures: a retrospective clinical study. Open J Stomatol. 2012;2:173-81. doi: 10.4236/ojst.2012.23032.

15. Müller F. Interventions for edentate elders-what is the evidence? Gerodontology. 2014;31(Suppl 1):44-51. doi: 10.1111/ger.12083.

16. Yamazaki T, Martiniuk AL, Irie K, Sokejima S, Lee CM. Does a mandibular overdenture improve nutrient intake and markers of nutritional status better than conventional complete denture?: a systematic review and meta-analysis. BMJ Open. 2016;6:e011799. doi: 10.1136/bmjopen-2016-011799.

17. Pun DK, Waliszewski MP, Waliszewski KJ, Berzins D. Survey of partial removable dental prosthesis (partial RDP) types in a distinct patient population. J Prosthet Dent. 2011;106:48-56. doi: 10.1016/S00223913(11)60093-0.

18. Radnai M, Saini R, Gorzo I. Removable partial denture with bar or plate: how should we decide? Int J Experiment Dent Sci. 2013;2:104 9. doi: 10.5005/jp-journals-10029-1050.

19. Ellakwa A. Damage caused by removable partial dentures: reality? Dentistry. 2012;2:e107. doi: 10.4172/2161-1122.1000e107.

20. Allen F. Factors influencing the provision of removable partial dentures by dentists in Ireland. J Ir Dent Assoc. 2010;56:224-9.

21. Mather $\mathrm{H}$, Thomason $\mathrm{M}$, Ellis J. Are UK graduates equipped with the skill set required to meet the demands of the UK's edentulous population? Br Dent J. 2018;225:15-18. doi: 10.1038/sj.bdj.2018.524. Epub 2018 Jul 6.

22. Polychronakis N, Sotiriou M, Zissis A. A survey of removable partial denture casts and major connector designs found in commercial laboratories, Athens, Greece. J Prosthodont. 2013;22:245-9. doi: 10.1111/j.1532-849X.2012.00922.

23. Nevalainen MJ, Närhi TO, Ainamo A. A 5-year follow-up study on the prosthetic rehabilitation of the elderly in Helsinki, Finland. J Oral Rehabil. 2004;31:647-52. doi: 10.1111/j.1365-2842.2004.01280.

24. Chau TN, Witter DJ, Kreulen CM, Creugers NH, Tu HH. Replacement of missing teeth in a southern region of Vietnam-a descriptive dental laboratory study. Int Dent J. 2009;59:192-6.

25. Poljak-Guberina R, Celebic A, Catovic A, Zivkovic O. Epidemiological study on removable denture deliveries in different districts of Croatia, 1996-2001 and 2002. Coll Antropol. 2005;29:127-32.

26. Official Gazette of the Republic of Slovenia, No. 106:11656 Accessed at: https://www.uradni-list.si/1/objava.jsp?sop=2012-01-4087.

27. Kosovo Agency of Statistics. Statistical yearbook of the Republic of Kosovo. Prishtina, Accessed 2017 at: http://ask.rks-gov.net/ media/4033/statistical-yearbook-of-the-republic-of-kosovo-2017. pdf.

28. Gašparić LB, Čatović A, Komar D, Bergman V, Ćatić A. Epidemiological study on prosthodontic appliance deliveries within elderly cohorts in the Republic of Croatia, 2002-2006. Coll Antropol. 2009;33:461-5. 
29. Niarchou AP, Ntala PC, Karamanoli EP, Polyzois GL, Frangou MJ. Partial edentulism and removable partial denture design in a dental school population: a survey in Greece. Gerodontology. 2011;28:17783. doi: 10.1111/j.1741-2358.2010.00382.

30. Rehmann P, Orbach K, Ferger P, Wöstmann B. Treatment outcomes with removable partial dentures: a retrospective analysis. Int $J$ Prosthodont. 2013;26:147-50. doi: 10.11607/ijp.2959.

31. Yamazaki S, Arakawa H, Maekawa K, Hara ES, Noda K, Minakuchi H, et al. Retrospective comparative ten-year study of cumulative survival rates of remaining teeth in large edentulism treated with implantsupported fixed partial dentures or removable partial dentures. J Prosthodont Res. 2013;57:156-61. doi: 10.1016/j.jpor.2013.03.003.

32. Moldovan O, Rudolph H, Luthardt RG. Biological complications of removable dental prostheses in moderately reduced dentition: a systematic review. Clin Oral Investig. 2018;22:2439-61. doi: 10.1007/ s00784-018-2522-y.

33. Ranfl M, Zaletel-Kragelj L. Assessment of the association between dentate status and self-rated general health. Zdr Varst. 2017;56:1319. doi: 10.1515/sjph-2017-0017. 